\title{
The Performing Arts and the Carnival, Calabar: Implications for Human Rights Protection in Nigeria
}

\author{
Jacob Udayi Agba.
}

\begin{abstract}
This essay is designed to evaluate the various forms and aesthetics of the performing Arts featured in the annual Carnival, Calabar and the human right implications of the carnival for movement of people and businesses during the $\tilde{A} ? \hat{A} \phi ? ? d r y$ runÃ $\hat{A} \phi ? ?$ rehearsals and actual carnival performance. Consequently, the essay attempts to address four core issues which are:

1. Impact of the Calabar Carnival,

2. The performing Arts,

3. Restrictions on Movement and attitude of criminals and

4. Implications for human right Protection.

Three hundred and sixty (360) respondents were involved in the evaluation. The data collected from the respondents were analyzed using the simple percentage. In addition, the principles guiding aesthetics of arts were used to describe the quality and symbolism of the Performing Arts involved in the Carnival, Calabar. Since Carnival, Calabar is performed largely in the street, the essay attempted to determine whether there is infringement on the fundamental rights of citizens within the period and location of the carnival and the role of the performing art in that infringement.
\end{abstract}

\section{Introduction}

The Encarta Dictionary says that the term Performing Arts refers to theatrical arts which are forms of art that involve theatrical performance, especially drama, dance, and music; while Wikipedia says Performing arts are art forms in which artists use their body or voice to convey artistic expression. Performing arts as a discipline is fugitive as it often takes the form and colouration of the cultural activities and events like, the Carnival, Calabar in which it is found. The Performing Arts is also impure, as it depends on other arts like Fine Art, speech art, music Art, visual arts and others to thrive. Thus, the Carnival Calabar is one of those opportunities available for the performing arts to display that impure quality to the full. What unifies both Performing arts and carnival as an art form are the uniqueness of situation and excitement. Carnival as used in this article refers to an interdisciplinary cultural festival presented in form of drama, music, dance and other cultural activities. It also involves competitions which unlike the performing art are performed in the streets rather than in the theatre. The fact that the carnival, Calabar is performed in streets not in theatres, therefore, implies that actions and policies surrounding the event must be planned and implemented to create conducive atmosphere for both the Performing Arts and the carnival to thrive. These policies and actions may positively or negatively affect the people close to the centre stage of the carnival. This has a lot of implication for human right as a social issue in a country like Nigeria in which democratic tenet is still in the process of being fully imbibed by the people. This is the paradox of the Carnival, Calabar. The carnival was no doubt, intended to entertain the people and subsequently, boost the tourism profile of Cross River State of Nigeria. Now it has become a thorn in the flesh of many Nigerians.

Part of activities to usher in the third millennium in Nigeria led to the nativity of the Calabar Christmas festival. Carnival, Calabar is part of the annual Christmas festival promoted by the government and people of Cross River State in Nigeria. Cross River State is a coastal state situated in south-eastern Nigerian border with Cameroon in the Central Africa to the East. It is named after the Cross River which runs through the state. Calabar, the State Capital is considered the tourism capital of Nigeria. Each year, thousands of visitors are attracted to the Cross River Christmas Festival. The Festival includes the display of international and local musical artists, the Carnival, Calabar, boat regatta, fashion shows, Christmas village and traditional dance displays.

Arising from the emergence of the Carnival, Calabar, therefore, two distinct issues can be identified as central to the management of the Carnival. These are the use of the performing arts employed to promote the Nigerian cultural festivals like dance, music, costumes and other decorations, tourism attractions and others, through the streets of Calabar and the issue of deprivation suffered by the people occasioned by restrictions of 
movement of people and goods along the carnival routes. As a preface to these core issues, the embodiment of the Carnival, Calabar has to be delineated.

In 2004, the former Governor of Cross River State in Nigeria, Mr. Donald Duke initiated the Cross River State Christmas Festival. This festival has become a most anticipated and talked about event attracting thousands of people from within Nigeria and beyond. It is a spectacular occasion, with thirty-one (31) days filled with celebration, culture, music, art, and endless activities. The Cross River State of Nigeria uses the occasion to showcase the rich culture, history and natural beauty of the State and celebrate her African heritage.

The Festival begins at the end of November with the Christmas tree lighting ceremony Dotted around the many interesting venues within the region. At the carnival, visitors can attend fashion shows, food demonstrations, cultural exhibits, talent shows, music concerts, funfairs, carol services, parades and picnics. The annual Boat Regatta is a colourful display of flamboyantly decorated boats, pitting local costal teams against each other. The Carnival, Calabar which has become the highlight of the festival is a showcase of performing arts replete with cultural heritage. Each year, participants demonstrate their skills, routines, masquerades and magnificent costumes during a parade that promenades along a 12kilometer route through the city of Calabar.

The Carnival, Calabar also known as "African's biggest street party" started in 2004 and has continued to attract a great number of people to the state. It has grown rapidly and has become the largest cultural attraction in Africa. The carnival is paraded as one of the longest festivals next to the Edinburgh revival that last for six weeks, with the number of participants increasing to over 2.3 million spectators.

According to Carnival Calabar Commission, (2010: 19), the Carnival, Calabar is rounded off every year on $26-27$ of December as highpoint of series of activities organized by the Cross River state government in Nigeria to celebrate both the end of year and Christmas season. Carnival, Calabar occupies the largest market share in Nigerian tourism sector. The number of attendance at Carnival, Calabar can be compared only to the Caribbean and nothing Hill festivals. The Carnival, Calabar is an annual socio-cultural event that impact greatly on the economic, social and cultural lives of the people of Cross River State in Nigeria and beyond; driven through the instrument of Performing Arts. It is also Performing Arts replete with unique display of African cultural heritage showcased through music, dance, drama and visual creativity reflected in the design of costumes and make-ups of the various features of the event. (Shone and Parry 2005, 55) observed that the event provides opportunity for visitors to enjoy the rich cultural heritage of the host community; while the host community shares her culture with the broader world.

According to research conducted by the Cross River State Carnival Commission in 2008, the carnival, Calabar attracted 1.2 million spectators in 2008 while in 2009 an estimated 2.34 million spectators directly or indirectly attended the event. These figures have continued to increase from year to year. (Mofinews magazine of January 2011,9 ) revealed that over 60,000 costumes, 2 million spectators and an audience of 50 million television viewers on international, national and local television networks participated in the 2009 edition of Carnival, Calabar. This status attained by the festival however can be attributed to the significant role of the performing Art; as through its various activities, the culture of Cross River State of Nigeria has been promoted on the global arena. Esu, in a personal communication with the researcher in 2010 opined that the carnival accounts for a large percentage of cultural promotion which is seen through the display of costumes, arts, music, historical sites etc., all geared towards the revival of culture. These however, set the platform for organizers to use historical and cultural themes each year to develop the event.

Programmes of the event are drafted each year by the committee in charge of tourism and cultural activities in Cross River State of Nigeria. Activities that precede the carnival include "carnival cup"-a football competition among the five bands that feature annually in the Carnival, Calabar, namely: Bay side, Seagull, Passion 4, Masta Blasta and the Freedom Bands. The carnival also features music performers from local and international artists, fashion shows, Carnival, Calabar Queen Pageantry as well as essay competition among students of secondary and tertiary institutions on the theme of the carnival.

The event has hosted top Nigerian musicians, Nollywood stars and international artist over the years. Carnival, Calabar is today, one of the famous festivals in Africa. It has been described as the cultural mosaic of the Nigerian people and this feat has been attained as a result of the Performing Arts displayed and experienced during the carnival.

The Carnival, Calabar over the years has contributed immensely to the promotion of tourism in the state as well as improvement in the socio-economic status of the state. However, much needs to be desired as I have been noted that during the event, rights of some citizens are violated; such as denial of access to some routes, abuse of children drafted to hawk along routes of the events and even raping of women and girls by hoodlums. Again, it is an observable fact that the western culture has over the years, invaded the culture of Nigeria vis-à-vis, the culture of Cross River State. It is equally difficult to determine the positive role of the performing art in the event as the carnival attracts other distinct forms of arts, and very high on-the-scene spectators who may not necessarily be there to appreciate the performing arts. Arising from these confusing situations, it is difficult to determine at a glance, the benefits of the Carnival, Calabar driven through the vehicle 
of the performing arts in diverse cultures. It is not also clear whether it is the culture of Nigeria, Cross River State or foreign nations that are promoted and it is not clear whether the people actually appreciate the Performing Arts as the same performing arts can be played out in times of protest against government and also to entertain; it is used to promote an unpopular government and it is also used to promote or suppress the rights of citizens.

Therefore, this essay among other things seeks to investigate what culture(s) and in what way(s) the Carnival, Calabar and the performing arts are driven; and whether or not the Carnival, Calabar and the Performing Arts in any way, help to violate the rights of citizens. Attempt would also be made to determine the specific role played by the Performing Arts in promoting Nigerian culture through the Carnival, Calabar. The article adopts historical as well as rhetoric-analytical approach to the discussion.

Before proceeding to highlight the implications of these obstacles and challenges, it is important to provide a conceptual basis for this discussion. A concept like a theory explains a phenomenon in order to provide greater understanding of a situation. It provides a form of standards for evaluating a phenomenon which are often reduced to statements of empirical laws. However, (McQuail 2005, 14) explains theory "not only as a system of law-like propositions, but as any systematic set of ideas that can help make sense of a phenomenon, guide action or predict a consequence"

The word carnival for some years now has become a household name in Calabar as

Most people both young and old look forward to the celebration each year. The event has formed the basis in which culture is being expressed, It encourages socio-economic development as and a typical means of marketing the tourism potential of Cross River State in Nigeria. At present a good number of people seem to lack knowledge of what carnival is all about it history, what it does for the people, how it is driven and what it is meant for.

The aim of this essay, among others is to bring to our knowledge the meaning of carnival, it origin, it socio-economic importance to the state, its impact on culture, its relationship with culture and the role of the performing arts in promoting the event as well as the implications of the Performing Arts and Carnival, Calabar in the protection of human rights in Nigeria. As this article develops, it will become clear that though the performing arts can be used in carnivals to entertain the people, if not properly driven, it can equally violate the rights of the citizens.

The word carnival according to (the Encyclopedia Americana 1829, 287) is a generally accepted derivation of the term 'carnem levare' or 'carnelevarium', coined from Medieval Latin. 'Carnem' means 'flesh' while 'levare' refers to abstinence from meat during the forty days of lent of the Christian year. Historically, the origin of carnival according to the encyclopedia is quite uncertain except that it is found in the pre-Christian customs. However, many scholars see links between the pagan Roman Saturnalia and Greek festivals with carnival; they regard carnival as an even more ancient agricultural rite connected with the theme of death and resurrection such as the spring festival in ancient Babylonia, Egypt, Greece and Rome.

Carnival therefore originated from a pagan custom during the pre-Christian period of Saturnalia- a custom which was modified by the church to become a two day festival before Ash Wednesday. Converts during this time were permitted to pay "farewell' to the devil, vanity and lust of the flesh before entering into the period of fasting and repentance for forty days of lent.

When Western European commercial capitalism intruded into the Caribbean and Latin America and was almost displacing the area and its indigenous people and institutions which nourished the spiritual nucleus of their religion, the West European ruling class brought the Africans to carry out forced labour in the sugar plantation. French planters and their slaves immigrated to Trinidad during the French revolution in 1789. Carnival was created when the laborers and slaves who saw the French celebrating in costume, and mimicked them while combining aspects from their own cultures. These Africans in turn brought with them their cultural customs, languages and artistic expression which were restricted to Sundays and Christmas holidays.

Carnival was later therefore taken out of the confines of the old slave master's Big Estates and brought out to the public arena of the streets where the freed Blackman gave full vent to their natural artistic, cultural and theatrical creativity of a popular mass level.

Fernando Ortiz, the late great Caribbean and Latin American author on African culture, customs and folklore (cited by the Trinidad and Tobago carnival website) also accounts for carnival history with a touch of Africa. He opines that it is assumed that carnival traditions were brought to the colonies in the new world by Europeans. He says when looking at today's streets carnival, it is quite clear that ancient African traditions have had a very strong influence on it. He added that the history of carnival can be viewed from different angles as a result of a cross cultural exchange that started centuries ago.

)The Encyclopedia Americana, 279) surviving carnival customs have been modified over the years by local folk traditions, these traditions are especially strong in rural areas where magical rites and observance, carried over from pre-Christian times mingle comfortably with Christian rituals and precepts. (New Encyclopedia Britannica 1968, 198) reveals that carnival right from its origin has continued to unite the world. It 
has become an annual celebration of life, found in many countries of the world today. The book adds that by learning more about carnival, we learn more about ourselves and a lot about accepting and understanding our culture and other peoples' culture. It has in its long history; continue to play a significant role in the development of the popular theatres, vernacular songs and folk dances.

\section{HISTORY OF THE CARNIVAL, CALABAR}

According to Atuake, the deputy director of administration of Carnival Commission in Cross River State of Nigeria (in a personal communication in 2009), Can be traced back to the 1980s where visitors and indigenes alike rushed to the round about to watch cultural displays performed by the Ekpe masquerades which was tagged "Ekpe festival". He said that the event which came up every December each year was an event that every true sons and daughters of the Efik kingdom in Nigeria looked forward to. Carnival Calabar therefore, according to him, is a gradual progression of the Ekpe dance to a bigger event that is being put together by the state government for the celebration of both Christmas and end of year.

The Carnival, Calabar which started formally as part of the celebration of the third millennium, according to pre-event brochure, (2008: 24) was initially used as one of the events to mark the Cross River State of Nigerian annual Christmas festival. According to the (pre-event brochure, 25) the event featured the performance of the models of the major land marks of Cross River State like the famous export commodity cocoa pod, the lowland Gorilla of the last rain forest of West Africa, the leopard of the Ekpe cultural group, the old residency building to mention a few. (The pre-event brochure, 29) further states that the carnival performance displayed today is as a result of the cumulative realization of band leaders and members adopting the drumming and singing style of the Africans in the Diaspora that was consistent with the village square band play form.

According to (carnival and event Brochure, 2009 15) in 2004, Mrs. Onari Duke, wife of the former Cross River state governor in Nigeria, introduced costume characters in order to give the event, depth and colour for variety. In order to further enrich the aesthetics of the performance in the Carnival, Calabar, the ex-governor of Cross River state in Nigeria, Mr. Donald Duke led a twenty- man team from the state to the Port of Spain in Trinidad and Tobago to participate in the 2005 carnival of that country in the Safari Band. While in 2007, the present governor of the state Senator Liyel Imoke introduced the cultural parade and children carnival thereby making the grand finale a two day event.

The Carnival, Calabar is composed of five competitive bands namely: Bayside, Passion 4, Seagull, Masta Blasta and the Freedom Band. Each year, a theme is fashioned out for the celebration. The king and the queen both of the carnival, each wears glamorous costumes that interpret the annual theme of the event and set the tone for other outfits. The theme of each band which is culturally driven however, ranges from freedom, emancipation to equality, valour etc. The programme of the event is drafted each year by the committee in charge of tourism and cultural activities. The event which features music performance from both local and international artist also features the Carnival Calabar Cup which is a football competition among the five competing bands, essay competition on the theme of the festival involving students of secondary and tertiary institution as well as the carnival Calabar queen pageantry.

The beauty of the festival is its acceptance by all the strata of the society, irrespective of whether the rights of the citizens are breached or protected; and it has become for the state and its people an ideal tool for tourism and ultimately socio-economic development. It has also become one of the drivers of economic activities in the Cross River state of Nigeria and indeed a tool for cultural advancement for Africa as a whole.

\section{CARNIVAL AS A TOOL FOR CULTURAL ADVANCEMENT}

Culture the world over has been acclaimed as a people's way of life. This includes their dressing, language, food, heritage etc. It is what the people believe in and stand for. Culture gives the people their identity. (Essoh and Oluwabamide 2005, 9) further explains this definition when they aptly articulate that culture is the learned socially acquired traditions and life styles of the members of a society including their patterned repetitive way of thinking, feeling and acting. (Bachleitner and Zins 1992, 204) broaden the definition by saying that culture is a medium evolved by humans to survive. According to them, nothing is free from cultural influences as it is the key stone in civilization, the medium through which all life events must flow. (Bachleitner and Zins 1992, 206) concludes, "We are culture", this explains why the people of Cross River State of Nigeria would stop at nothing to ensure that their cultural heritage is revived and preserved.

The carnival, Calabar as a whole is a cultural event. The cultural activities displayed during the festival are worthy of note. These displays however, are not only drawn from the host state alone, but cut across the different states of the Nigerian federation and indeed Africa as a whole. According to the (Carnival Calabar preview 2009, 14) the bringing together of cultures stands out as a powerful symbol of Nigerian unity; showcasing ethnic customs and traditional dresses across the country. It shows the unity of Nigeria in diversity 
as both visitors and indigenous people alike, parade their culture by dancing and marching, showing the modern multicultural Nigeria and her fascinating cultural history.

Hill Abrahams and Ray Funk in the Nigerian Chronicle of December 2, 2009, states, "whatever the carnival may be, in their many incarnations, they are a product of unique culture and crucibles for creating discovering and asserting identities", according to the initiator of the festival, former governor of Cross River State. Donald Duke, in a personal communication, December 2004, "my vision is to ensure that cultural values and contents form a major component of the experience of the carnival, the blend of cultural dance troupes drawn from across the state are to participate for a total experience". Similarly, the wife of the former Governor of Cross River State of Nigeria, Onari Duke said that without culture there will be no nation that is why culture needs to be revived and sustained through carnival.

As a result of the entire cultural spectacle imbedded in the festival, the event is now being regarded as a tool to develop new forms of looking at the world and its cultures, and a tool for cultural advancement.

\section{THE RELATIONSHIP BETWEEN CARNIVAL AND CULTURE}

Carnival and culture have a whole lot in common. Just like carnival is an integral aspect of human life, culture too is the totality of human life and culture is seen in the eyes of carnival. Carnival is a product of culture and one cannot do without the other. The centrality of carnival to cultural sustenance of Trinidad and Tobago has been stressed in the various Carnivals, Calabar pre-event publications. However, these publications have opened a new window on carnival, highlighting carnival as a space in which history as memory and national heritage are continually being made and remade. This explains why most countries that organize carnival do it in a way that it can teach young people about their roots and culture; and one of the best ways to teach young ones, is through the performing arts, as it provides the avenue for young people not only to see physically socio/cultural features of their society, but it offers them the privilege to practically experience the working of their culture. For instance, in Trinidad and Tobago Carnival, hundreds of schools and community organizations participate in order to revive the culture and the same can be said of children and community organizations in the Carnival, Calabar in Cross River State of Nigeria. For instance, in the carnival, children are dressed in a way that reflects the cultural heritage of the state.

According to (carnival and event brochure 2009, 32) in a bid to make carnival a cultural event, the former Governor of Cross River State, Donald Duke has ensured that communities work together to develop stronger friendship and greater love for their respective cultures and the other cultures of the world. (Carnival Calabar preview 2009, 35), declares that carnival is an art, and as an art, it offers as all dynamic arts, the tool as self expression and exploration which helps us go out in search for our roots which is our cultural heritage, and this ultimately, helps us celebrate what make us different from the rest of the peoples of the world.

Carnival like culture creates a sense of value and belief in individual or the culture of a community. It helps the people to appreciate what they have as a people, it enables visitors to interact with the host community and helps the people enjoy and meet with others. Carnival provides both the host community and visitors alike with a unique vibrant and valuable culture. For example, Masta Blasta band, one of the bands that features in the Carnival, Calabar also reflects the culture of the people and government of Cross River State of Nigeria, by decorating their trucks with gold of Africa, farmers and their harvest, the pyramid of Egypt, Diamond, crude oil etc. while Bayside Band has come up with the interpretation of cradle of human civilization, the tourism industry, bravery, resilience, talent, adventure, pains and tears among Nigerians and Africans etc. All these have much in common with performing arts and have significant impact on culture. Even the twelve kilometer route of the carnival is adorned at different road junctions with different works of arts. (Duruaku 1997, 19) describes the Performing Arts as "impure arts" that depends on other works of art. For instance, at the Mary Slessor by Marian Hill round about in Calabar, you find the work of art depicting Mary Slessor, a Scottish missionary who came to stop the killing of twins in Calabar, holding a baby on her arms with a woman beside her, apparently, the forsaken mother of twins. At the Mary Slessor by the University of Calabar, main gate round about, you find a work of art depicted by the symbol of a lantern. All these works of arts along the streets of the carnival add colour to the Performing Arts, they serve as the various the design creating the stage for the carnival performed through the vehicle of the Performing Arts.

\section{IMPACT OF PERFORMING ARTS ON CARNIVAL}

Carnival as stated earlier is a socio-cultural event that reflects the culture of the people. However, it is most strongly driven by the performing arts. In order to make the festival strictly a cultural event and to make it influence culture, the following performing arts elements are employed by the organizers:

\section{a) COSTUMES}

Costumes are some of the most important features in the carnival, Calabar, as it is what represents a people. The costumes are done in a way to interpret the carnival theme which is all based on cultural heritage. For instance, the 2009 carnival which had as its theme "land of our birth our people our culture" has other ethnic 
groups participating in the event and they were distinguished by their costumes. The Yoruba men dressed in their traditional Agbada; while the Yoruba ladies were dressed in their traditional women outfit called, "asoke". The Hausas came out with their horses, portraying their nomadic life style and other costumes that make up their culture; while the Efik people of Cross River State of Nigeria were not left out as they displayed their famous Ekpe cultural dance and the most recent one known as "Etighi" dance; and their women were adorned with the acclaimed Efik traditional dress known as "Onyonyo" gowns. The Efik also displayed their Ekombi dance. All these, tell a story of a people and their belief in their different cultural heritage.

b)

HERITAGE

Culture encompasses the total being and heritage; as a result, the themes of the festival have always been carefully drawn from our cultural heritage and Africa at large. The 2008 edition had the theme sustaining earth's treasures through our culture", the 2009 had "land of our birth, our people, our culture", and the 2010 had the theme "our strength and resilience, the birth of our future".

The theme for 2011 was "endless possibilities" while the theme for the 2012 carnival Calabar was "the new dawn".The Miss Carnival, Calabar Beauty pageant is also another event replete with performing arts. According to (Mofinews magazine 2011,5) the contestants during Carnival, Calabar contest are identified with names of prominent places in Cross River State of Nigeria that tell the history of the country; such as tourist sites, historical buildings, mountains, resorts and parks etc. Thus, the contestants are christened with names such as Miss Alok Monolith, Miss WAPI, Miss Marina Resort, Miss National Park to mention a few. The dance and music; all elements of performing arts, interpret the theme of the years celebration which is derived from culture.

The Essay Competition on the theme of the festival which is a literary aspect of the performing arts often made part of the carnival. According to Dokubo Elena Osima the Secretary to the Cross River State Carnival Commission, in a personal communication, (2011), the essay competition is aimed at encouraging the revival and sustenance of the Cross River State of Nigeria cultural heritage.

\section{INFLUENCE OF THE PERFORMING ARTS}

According to (Tolstoy in Camp Julie Van, jvancamp@csulb.edu) one of the means of intercourse between man and man. Every work of art causes the receiver to enter into a certain kind of relationship both with him who, simultaneously, previously, or subsequently, receives the same artistic impression. Tolstoy believes that the speech, transmitting the thoughts and experiences of men, serve as means of union among them, and art acts in a similar manner. By words, a man transmits his thoughts to another, by means of art, he transmits his feelings. is based on through art a man receives through his sense of hearing; or sight; another man's experiences or feelings expressed in words capable of making others experience the feelings and experiences so expressed. Thus, by his movements or by the sounds of his voice, a man expresses courage and determination or sadness and calmness, and this state of mind passes on to others. A man suffers, expressing his sufferings by groans and spasms, and this suffering transmits itself to other people; a man expresses his feeling of admiration, devotion, fear, respect, or love to the same objects, persons, and phenomena.

To Tolstoy, it is upon this capacity of man to receive another man's expression of feeling and experience those feelings himself, that the activity of art (the performing arts) is based

To Tolstoy, Art begins when one person, with the object of joining another or others to him in one and the same feeling, expresses that feeling by certain external indications. To take the simplest example: a boy, having experienced, let us say, fear of encountering a wolf, relates that encounter, and, in order to evoke in others the feeling he has experienced, describes himself, his condition before the encounter, the surrounding, the woods, his own light-heartedness and then the wolf's appearance, its movements, the distance between himself and the wolf, etc. All this, if only the boy, when telling the story, again experiences the feelings he had lived through and infects the hearers and compels them to feel what feelings he had lived through and infects the hearers and compels them to feel what he, or the narrator had experienced is performing arts. If even the boy had not seen a wolf but had frequently been afraid of one, and if wishing to evoke in others the fear he had felt, he invented an encounter with a wolf and resounds it so as to make his hearers share the feeling he experienced when he feared the wolf that also would be performing arts. And just in the feeling, he experienced when he feared the wolf that also would be performing arts. And just in the same way. It is performing arts if a man, having experienced either the fear of suffering or the attraction of enjoyment (whether in reality or in imagination) expresses these feeling on canvas or in marble that are part of a theatrical design, so that others are infected by them. It is also performing arts if a man feels or imagines to himself feelings of delight, gladness, sorrow, despair, courage, or despondency and he transfers these feelings from him to others and cause others to transfer the feelings to another. It is performing arts when a man expresses feelings or thoughts by sound or any other form of music that is part of the performing arts, as experienced by the composer. 
This is precisely what performing arts has been used as a vehicle to drive Calabar-Nigerian and other foreign cultures captured in Carnival, Calabar.

(Tolstoy in Camp, Julie Van jvancamp@ csulb.edu.) observes that the feeling with which the artist infects others may be most various - very strong or very weak, very important or very insignificant, very bad or very good: feelings of love for one's own country, self-devotion and submission to fate or to God expressed in a drama, raptures of lovers described in a novel, feeling of voluptuousness expressed in picture, courage expressed in a triumphal march, merriment evoked by a dance, humor evoked by a funny story, the feeling of quietness transmitted by an evening landscape or by a lullaby, or the feeling of admiration evoked by a beautiful arabesque - it is all art.

If only the spectators or audiences are infected by the feeling which the performers or the playwright has felt, it is performing arts. To evoke in oneself a feeling one has once experienced, and having evoked it in oneself, then, by means of movements, lines, colors, sounds, or forms expressed in words, to transmit that feeling in a way that other may experience the same feeling - this is the essence of the performing arts.

The entire carnival, Calabar is a creative work of art. This is reflected in the way the different bands artistically design and decorates their trucks in a quest to interpret the theme of the festival. Performing Art is culturally driven and as such, one cannot discuss culture without arts. For Example, Freedom band whose band's theme is based on freedom is usually decorated with history of tribal wars, era of slavery etc. It also focuses on Nigerian tribes such as Efik, Yoruba ${ }_{2}$ Ibo, Hausa and other African tribes; such as those of Kenya, Cote D' voir etc The ethnic subcultures are depicted by way of their costumes, dances and songs, all in tune with the carnival.

Unfortunately, during the preparation and actual display of the Carnival, Calabar, Some streets in Calabar, are closed, restrictions of movement of people and goods enforced while chaos in the transportation system among other ugly social trends are experienced by the people. This has been interpreted by me, as a violation of the basic human right of the people of Calabar in particular, and Nigeria as a whole.

What then is human right? Before the declaration of independence in the U.S., Jefferson in Goodridge 2001,38 ) expressed the ideals of liberty and equality that would shape U.S. Government and public policy:" We hold these truths to be self-evident, that all men are created equal that they are endowed by their creator with certain inalienable rights, that among these are life, liberty and the pursuit of happiness...That to secure these rights, governments are instituted among men, deriving their just powers from the consent of the governed ."I believe that Jefferson was not referring to physical equality. I am sure in our circumstance, he meant equality in the use of the twelve-kilometer route for the Carnival, Calabar, the performing arts, packaged to drive the Carnival, Calabar and other elements making up the Carnival, Calabar. Furthermore, "liberty and the pursuit of happiness" are established not only as legal rights, but as "Unalienable Rights" to be given special respect when formulating our policies including policies about Carnival, Calabar. Lastly, Jefferson clearly states that government primary charge is to preserve these rights and that when acting to do so must have the consent of those it affect. In this sense, therefore, if the government of Cross River State feels that the restrictions in the use of roads during the dry run rehearsals and the actual staging of the Carnival, Calabar is to preserve the rights of the people, the people must be consulted for their views on the issue and to do otherwise, is to violate the rights of the people.

Scholars have attempted to base a universal "right to movement" on several philosophical grounds, including the idea of a common ownership of the earth, a natural right of movement existing prior to the advent of nation states, an ethics of cosmopolitanism, and utilitarian notions of the benefits of immigration to both receiving countries and immigrants. It is a truism that many Nigerians including citizens of Cross River State of Nigeria have learned to live with their difficulties; perhaps, that is why there is no formal protest against the violation of their right to movement. No doubt, one cannot rule out feelings of frustration and disappointment in the people as a result of road closures or restrictions of movement of persons and goods. This is therefore, the reason why it is necessary to carry out some survey to find out how Nigerians living in Cross River State feel about the closure of roads and subsequent restrictions of movement during carnival performance along the streets. This is why I have to carry out the limited survey on the way residents of Calabar, Nigeria feel, regarding the closure of roads and restrictions of movement of persons and goods during the period of the carnival. The result of the survey is presented in the tables below:

Table 1: showing the Degree of Frustration Expressed by 360 Respondents

\begin{tabular}{|l|l|l|l|l|l|l|}
\hline $\begin{array}{l}\text { Reason for Road Closure } \\
\text { and Degree of Frustration }\end{array}$ & $\begin{array}{l}\text { Extremely } \\
\text { Annoyed }\end{array}$ & $\begin{array}{l}\text { Very } \\
\text { Annoyed }\end{array}$ & Annoyed & $\begin{array}{l}\text { Fairly } \\
\text { Annoyed }\end{array}$ & $\begin{array}{l}\text { Not } \\
\text { Annoyed }\end{array}$ & Total \\
\hline Carnival Performance & $240(66.7)$ & $30(8.4)$ & $\begin{array}{c}60 \\
(16.66)\end{array}$ & $30(8.4)$ & $0(0)$ & $\begin{array}{l}360 \\
(100)\end{array}$ \\
\hline Carnival Dry Run & $300(83.3)$ & 8.3 & $30(8.3)$ & $0(0)$ & $0(0)$ & $\begin{array}{l}360 \\
(100)\end{array}$ \\
\hline
\end{tabular}


The Performing Arts And The Carnival, Calabar: Implications For Human Rights Protection In

\begin{tabular}{|l|l|l|l|l|l|l|}
\hline $\begin{array}{l}\text { Movement of Government } \\
\text { Officials }\end{array}$ & $120(33.3)$ & $\begin{array}{l}180(50) \\
30(8.3)\end{array}$ & $30(8.3)$ & $30(8.3)$ & $0(0)$ & $\begin{array}{l}360 \\
(100)\end{array}$ \\
\hline Movement of Cash & $\begin{array}{l}100 \\
120(33.3\end{array}$ & $\begin{array}{l}100(27.8) \\
(2)\end{array}$ & $40(11.1)$ & $0(0)$ & $\begin{array}{l}360 \\
(100)\end{array}$ \\
\hline Movement of Security Men & $200(55.6)$ & $\begin{array}{l}100(27.8) \\
30()\end{array}$ & $20(33.3)$ & $24(40)$ & $16(26.7)$ & $\begin{array}{l}360 \\
(100)\end{array}$ \\
\hline Party & $\mathbf{3 0 0}(\mathbf{8 3 . 7}$ & $\mathbf{4 0}(\mathbf{1 1 . 1})$ & $\mathbf{1 0 ( 2 . 8 )}$ & $\mathbf{1 0}(\mathbf{2 . 8})$ & $\mathbf{0}(\mathbf{0})$ & $\begin{array}{l}\mathbf{3 6 0} \\
(\mathbf{1 0 0})\end{array}$ \\
\hline
\end{tabular}

(Figures in parenthesis indicate percentages).

Table 2: showing Respondents' rating of Human Right Violation in Calabar

\begin{tabular}{|l|l|l|l|l|}
\hline $\begin{array}{l}\text { Respondents' Rating of Human Right } \\
\text { Violation In Calabar }\end{array}$ & Very High & Very Low & No Violation & Total $(83.3)$ \\
\hline During Carnival: & $350(97.2$ & $10(2.8$ & $0(0)$ & $360(100)$ \\
\hline Outside Carnival & $60(16.7)$ & $300(83.3)$ & $0(0)$ & $360(100)$. \\
\hline
\end{tabular}

(Figures in parenthesis indicate percentages).

Tables $1-2$ show data from a limited survey of the level of frustration occasioned by the closure of roads in Calabar during periods of annual Carnival and their rating of the degree of human right violation.

This survey was deliberately limited because it had to do only with this segment of the paper. It was not the focus of the paper nor was the paper based on the survey's findings, but even within its limited scope, data reveal an uncomfortable frustration and high level of human right violation within the routes of the carnival. For example, though 83.7 percent of those surveyed claimed extreme frustration following the restriction of movement during Carnival and the dry run rehearsals preceding the carnival as well as over $92 \%$ very high rating of human right violation, a considerable level of frustration was still expressed by the respondents with the restriction of movement of persons due to other reasons for road closure such as movement of government officials, movement of cash, movement of security officials and holding of parties by some residents of Calabar.

It is therefore, my opinion in this paper that while the cultural enrichment of carnival makes the staging of carnival as a processional theatre imperative, the closure of roads and subsequent restriction of movement appears to violate the rights of many; including those interested in participating in the carnival and those not interested in participating in it. From the findings of the survey conducted for this paper, many residents of Calabar are extremely frustrated by restriction of movement while they feel that

their human rights are very highly violated.

\section{Conclusion}

This paper was not only intended to romanticize the beauty of Carnival, Calabar, nor was it intended to completely discredit the event, but it was to examine critically, the benefits and harm perpetrated by the carnival. Though the carnival, Calabar entertains the world through various forms of performing arts, as (Goodridge 2001, 44) remarks, outside the period of wars and other insecurity, movement of persons on the road is part of human right. The paper suggests that if the Carnival would truly entertain without violating the rights of the residents of Calabar, there is need for the government of Cross River State to conduct the dry run rehearsals for the carnival and the actual carnival performance along carnival designated routes or at a time that no restriction on movement of persons would be necessary. It also argued that Performing the carnival in the streets may be the tradition of the carnival as a processional theatre, but restricting movement of people along carnival routes may not be the best way of entertaining the people for whose interest the carnival was in the first instance, taken to the streets. In the same way, frustrating local population along streets for the purpose of entertaining the world is not necessary because the world can watch the carnival even from a reserved location on screen, after all, Olympic events and other major world tournaments are not conducted on the streets. If restrictions on movement and closures of roads and streets are due to the participation of government dignitaries, then, let such public figures participate from bullet proof vehicles, so that the essence of carnival as processional theatre could be realized.

\section{References}


[1]. Bachleitner, Richard, and Zins, Arnold. 1992. "Cultural Tourism in Rural Communities: The resident's perspective”. Journal of Business Research 44: 199 - 209. 199 - 209.

[2]. Carnival Commission. 2009. Carnival Calabar Preview Calabar: Nigeria.

[3]. Carnival Commission. 2008. Pre-event brochure. Calabar Nigeria.

[4]. Duruaku, ABC. A Handbook on Drama and Theatre. Owerri Colon Concept LTD., 1997.

[5]. Essoh, Peter A. and Oluwabamide, Abiodun J., eds. 2005. Highlights of the Nigerian Heritage. Lagos: Lisjohnson Resources Publishers.

[6]. Goodridge, Stephen G. The Right to Travel by Human Power. 2001. Bicycling Life Website, http://www.ladybrillemag.com/2009/01. Retrieved May 22, 2012.

[7]. Lindberg, Kenneth. The economic impact of eco-tourism, 1996, Available at http://www.ectorom.ac/okoking./htm.

[8]. McQuail, Denis. 2005. Mass Communication Theory $5^{\text {th }}$ ed., London: Sage Publications.

[9]. Mofinews Magazine. 2011. “Africa’s biggest street party”. Journal of Ministry of Finance. Calabar, Nigeria.

[10]. Rommen. Timothy. Latin American Music Review/Revista de Música Latinoamericana. Vol. 29, No. 2 pp. 263-268. Available at http://www.jstor.org/stable/29739160

[11]. Shone, Arnold and Parry, Bernard. 2005. Successful event management: Practical handbook, $2^{\text {nd }}$ ed. London: Thomson Learning.

[12]. Smith, Miller. 2004. Seeing a new side to seaside's culturally regenerating the English. Seaside Town.

[13]. Tolstoy, Leo, In Camp, Julie Van. jvancamp@ csulb.edu. Retrieved, February 9, 2011.

[14]. Tourism Commission. "Welcome to paradise Cross River State". Platform branding Calabar.

[15]. Wikipedia, Human Rights and the Freedom at "http://en.wikipedia.org/w/index.php?title=Freedom_of_movement\&oldid=476553605 Retrieved March 24, 2012. 